\title{
Role Stressors and Job Satisfaction in the Banking Industry: The Mediating Role of Job Stress
}

\author{
Syed Talib Hussain ${ }^{1} \&$ Shen Lei ${ }^{1}$ \\ ${ }^{1}$ Glorious Sun School of Busniess and Mangement, Donghua University, Shanghai, China \\ Correspondence: Syed Talib Hussain, Glorious Sun School of Business and Management, Donghua University, \\ West Yan'an Road 1882, Shanghai 200051, China. Tel: 86-150-0171-5310. E-mail: talib_14@yahoo.com
}

Received: June 22, 2015

Accepted: July 30, 2015

Online Published: August 25, 2015

doi:10.5539/ibr.v8n9p105

URL: http://dx.doi.org/10.5539/ibr.v8n9p105

\begin{abstract}
In banking sector, the retail banking is an important and generous sector of economy and job stress becomes progressively visible and increasing in this sector, after a series of arrangements for financial institutions. Therefore, the study of specific causes of job stress in the retail banking area should provide greater approach into both, theoretical and managerial practices. Several Studies have been conducted on role stressors and job satisfaction. The purpose of this study is to determine the effect of role stressors on job satisfaction by using job stress as mediator variable by applying different mediation approaches. The total distribution was 350 and questionnaires were collected from 305 employees and response rate was 87 percent. In the results of Correlation and Regression analysis, it was found that, role ambiguity and role conflict have negative relationship with job satisfaction. In the result of Regression it was concluded that job stress has influences among role ambiguity, role conflict and job satisfaction. The findings of the study suggest that role stressers should be controlled in order to increase the job satisfaction. Hence lesser the role stressors, lesser will be the job stress.
\end{abstract}

Keywords: role ambiguity, role conflict, job stress, job satisfaction, classic approach, contemporary approach, banking sector

\section{Introduction}

Technological revolution, mass retrenchments, mergers and acquisitions, information excess, demand for more production, tough competition and tentative outlook have created stress in workplace. As a result of these transformations, high stress level and lower job satisfaction are found in banking sector. Banking employees acknowledged, that, their jobs, family life and health have been affected by stress. Advanced and boom up economy pressure, for maintaining profitability, large and maximized responsibilities are chief roots, which cause stress. Potential for conflict exists in every organization. In the face of that, slight consideration has been given for organizational behavior analysis. This difficult observable fact brings allegations to community life and the understanding of it, offers impending in a more effective organizational management. Organizations are well-off fields to study conflict, the reasons are highly needy circumstances that involve ability, hierarchical influence and groups (Ahmadi \& Alireza, 2007). Physical science defines stress as "the force placed upon an object to cause breaking, straining or bending" (Ahmadi \& Alireza, 2007). But in human perception and psychology, stress is a threatening thing on the placement of favorable or unfavorable demands upon it. If the demand being placed exceeds our ability, then human perceives stress. All these things which cause stress are called stressors. Stressors are factors which affect the role of employees in organization, which are role conflict, role ambiguity and role overload (Singh, Goolsby, \& Rhoads, 1994). Role conflict occurs due to job demands, role ambiguity occur due to lack of clear information, and role overload occurs due to excessive work on the employees (Larson, 2004). Role overload and role conflict seem that they are the same variables but actually they are different concepts (Kahn et al., 1964). Growing emphasis on flexible work arrangements, organizational change, autonomous working conditions and employee empowerments have constantly changed the role uncertainty and job specifications. Subsequently, losing stable job boundaries increase the potential for role stress (Cooper \& Dewe, 2004). Coleman (1976) states the modern world as the age of stress and anxiety. Stress is flattering in workplace, which influences a number of people negatively (Cox et al., 2000). A study was conducted in Pakistan and was concluded that most of the managers did not exploit their abilities because they have stress (Ram et al., 2011). The encouraging aspect of the stress is that if it is properly managed, then it will 
increase the motivation level of employees and best performance will be achieved easily (Robbins, 2007). A happy, cheerful and hard-hitting employee is the prime asset of any organization and bank is one of them. Personnel of any bank are accountable to a huge output and prosperity. Competent human resource management and keeping higher job satisfaction level in banks agree not only on the performance of the bank but also influence the enlargement and performance of the whole economy. Thus, for the success of banking sector, it is vital to handle human resource successfully for the purpose that their employees are happy or not. If the employees are happy and satisfied, so they will be committed to their work and they will have a good image for the organization (Bashir \& Ramay, 2010).

The study purpose was focused on predictive effects of role ambiguity, role conflict and job stress on the degree of job satisfaction. This kind of studies may be influential to administrators for better long term achievements employed in banks. The study identifies role stressors issues which influences the banking employee's job satisfaction. For this research the banking sector was selected because this sector has been constantly recognized as a group of having high stress at work. Consequently, the problem would be investigated in this study to find out whether relationship exists among role conflict, role ambiguity, job stress and job satisfaction in private banking sector as well as to find out the greater interaction of the three variables with job satisfaction.

\section{Literature Review}

\subsection{Role Conflict, Role Ambiguity and Job Stress}

The effect of role stressors (role ambiguity and role conflict) does not directly relate to job stress but mediate by job insecurity (Safaria, Othman, \& Wahab, 2011). Different programs have been developed to increase the effectiveness of the employees but these lead to ambiguity and stress. Role ambiguity is the cause of lack of clear definition of expectations of the employees which is required for the performance of the duties (Chen et al., 2008). Those salespersons who don't have adequate information will face ambiguity in doing their work which can affect their performance (Moncrieff, Babakus, Cravens, \& Johnston, 1997). Low perceptions of role overload and role conflict will most likely result in low role stress that in turn will have positive consequences for both organization and employees (Malik et al., 2010). According to Chen and Lien (2008), role conflict is the inconsistency in the expectations and demands of different parties in the organization. When both parties are involved, then the problem will be that which party's work should be done first and which work should be done later. So as a result of this, conflict will occur in the role. In such situation both parties are not possible to be satisfied and thus the performance will be affected. When such two roles are given to one person, it will be difficult to reconcile and take help from two different supervisors. In such type of situation, the person will experience job stress. The employees who are experiencing the role conflict concluded that they cannot perform properly, and they are enforced to additional resources for their work role and this may be the loss of resources which results in dissatisfaction and psychological strain (Hobfoll, 1989). The studies of Fisher and Gittleson (1983) and Johnston, Parasuraman, and Futrell (1990), postulate that there is positive and direct influence between role conflict and job stress. Jackson and Schuler (1985) studied that there exists negative impact of role conflict on stress, commitment, worker participation and turnover. So according to the literature, the following hypotheses were developed.

H1: High role ambiguity is an indicator of high job stress in several complex antecedent configurations for high job stress.

H2: High role conflict is an indicator of high job stress in several complex antecedent configurations for high job stress.

\subsection{Job Stress and Job Satisfaction}

Landsbergis (1988), states that when the level of work stress is higher, then the level of job satisfaction will be lower in such situation. In the study of Usman, Ahmed and Akbar (2011) it was concluded that job dissatisfaction was found and its cause was work stress while in case of job satisfaction the level of work stress reduces. In the study of Yousef (2002) it was found that role ambiguity and role conflict have a direct relationship and the relationship was found as negative. The study of Wu and Norman (2006) concludes that the job satisfaction and role stress which are role ambiguity and role conflict have negative relationship. Job satisfaction has negative relationship with work overload (Bradley \& Cartwright, 2002). There is negative relationship between job satisfaction and time pressure (Robinson, Roth, \& Brown, 1993). In the study of Schaefer and Moos (1993) it was found that there was negative relationship between job satisfaction and system stressors (work load and scheduling). Role stressors affect the job stress and job stress affects job satisfaction negatively (Ahsan, Abdullah, Gun Fie, \& Alam, 2009). Negative relationship was found between the nurses and doctors' job satisfaction and job stress (Konstantinos \& Christina, 2008). In the study of Stamps and Piedmonte (1986) it was 
found that there is a significant relationship between job stress and job satisfaction. The study of Cooper et al., (1989) found that there are four job stressors that were predictive of job dissatisfaction. In the study of Vinokur-Kaplan (1991) it was identified that workload and working conditions were negatively linked to the job satisfaction. The study of Fletcher and Payne (1980) stated that the job stress and job satisfaction are interrelated. Landsbergis (1988) identified that when there is high level of work stress then there will be low level of job satisfaction. Cummins (1990) identified that job stressor is prophetic for job dissatisfaction and there will be more tendency for leaving the organization. Sullivan and Bhagat (1992) indentified that the relationship between job stress and job satisfaction is positive or negative or have no relationship at all. Babin and Boles (1996) identified that role stress has negative relationship with job satisfaction. Many studies have examined the dimensions of job satisfaction and job stress variables instead of overall measures. The study of Nobile, McCormick (2005) identified that the staff members of primary school whether teaching or non-teaching staff were satisfied from their work while the same group was also experiencing stress. Goolsby and Jerry (1992) found in their research low job satisfaction and low organizational commitment. The theoretical research supports the indirect effect of role conflict and role ambiguity on low job satisfaction and organizational commitment. Lu, Tseng and Cooper (1999) studied that role stressors were correlated positively to intention to leave the organization while a negative relationship was found between the role stressors and job satisfaction.

On the basis of above literature, the following hypothesis is developed.

H3: Higher level of job stress experienced at work will be predictive of lower level of job satisfaction.

\subsection{Role Stressors, Job Stress and Job Satisfaction}

In the study of Lourel et al. (2009), it is concluded that the perceived stress has mediated the relationship between home work interface and job satisfaction. According to Yousef (2000) together role conflict and role ambiguity do not affect the job satisfaction but they affect the job satisfaction separately.

Role conflict experienced by single mother employees at the workplace can increase the conflict in meeting the demands of work and family roles which in turn can reduce the level of job satisfaction (Ahmad et al., 2007). The relationship between role ambiguity and role conflict with job stress mediated by job insecurity is significant (Safaria et al., 2011). Yousef (2000) studied that role stressors together do not affect the job satisfaction but they can affect the job satisfaction separately.

Higher the level of role conflict, lower will be the level of job satisfaction and vice versa (Higgins, Duxbury, \& Irving 1992). In the study of Yousef (2002) role stressors have direct and negative relationship with job satisfaction. Wu and Norman (2006) investigated that there is negative relation between role stressors and job satisfaction. The study of Bhagat, McQuaid, Lindholm and Segovis (1985) identified negative relationship between job satisfaction and work conflict. Role conflict has strong effect than role ambiguity on job satisfaction (Netmeyer, Johnston, \& Burton 1990). Sager (1994) studied that role conflict directly affects job satisfaction and job stress. In the study of James, Boles, Wood and Johnson (2003), negative relationship was found between work family conflict and the job satisfaction facets which are satisfaction with pay, promotion policy and supervision. In the study of Yousef (2002), it was concluded that there is direct and negative influence in role stressors and job satisfaction. Bedeian and Armenakis (1981) and the study of Jackson,(1983), identified that the role stressors have direct effect on stress and burn out and job satisfaction and indirect causal relationship with job satisfaction. The study of Goldstein and Rockart, (1984) identified a negative association between job satisfaction and role stressors. Baroudi, (1985) stated in his research that the role stressors (R.A \& R.C) have impact on the personnel job satisfaction and the organizational commitment and also have impact on intention to quit the organization. In the study of Babin and Bales, (1996) showed that there exists relationship between job satisfaction and work family conflict. Bedian, Burke and Moffet (1988) studied and found that there is no relationship between work-family conflict and job satisfaction. The study which reported that there is relationship between work family conflict and job satisfaction and the one which reported that there is no relationship between work family conflict and job satisfaction both used the Global Measure of Job satisfaction.

H4: High role ambiguity is an indicator of lower job satisfaction in several complex antecedent configurations for lower job satisfaction.

H5: High role conflict is an indicator of lower job satisfaction in several complex antecedent configurations for lower job satisfaction.

H6. Job Stress mediates the relationship between role stressors (role ambiguity \& role conflict) and Job Satisfaction. 


\section{Methodology}

\subsection{Design}

This study was conducted in private banking sector only in Pakistan. Different private banks were considered for study. For collecting the data close-ended questionnaire, population size, cost and time constraints were considered for the study. The study exploits systematic process of multiple regression to establish whether role conflict, role ambiguity and job stress predict a score on employees job satisfaction questionnaire. The banks and employees were randomly selected for this study.

\subsection{Data Collection Procedure}

The total distribution was 350 and response rate was 305 (87\%). The data was collected from banking sector in Pakistan. The convenient method was used for data collection. The sample was participated voluntarily, study purpose was explained clearly and they were allowed to participate or decline if someone does not want to participate. The questionnaires were distributed and assembled inside the envelopes. The questionnaires were filled at home or at banks. The information given by employees was kept completely confidential.

\subsection{Data Collection Measures and Reliability Test}

All items of role conflict, role ambiguity, job stress and job satisfaction were responded to on a 5-point likert scale. Role Stressor Scale (RSS) was used and it was developed by Rizzo, House and Lirtzman in (1970). The Cronbach alpha value is 0.786 and the range was 0.83 (Jamal \& Baba, 1992). This scale consists of eight items. The Cronbach alpha value is 0.758 and the range was 0.71 to 0.95 (Adkins, 1995). Job Stress Scale (JSS) was used by Jamal and Baba in 1992 with a summarized version of the Job Stress Scale consisting of nine items. For the measurement of Job Satisfaction, Global Job Satisfaction (GJS) was used and was developed by Quinn and Shepard (1974), and was modified by Pond and Geyer (1991), and Rice et al. (1991). The Cronbach alpha value is 0.870 and the range was 0.89 (Pond \& Geyer, 1991). For all variables the Five Point Likert Scale was used.

\subsection{Data Analysis Method}

Different statistical tools were used for data analysis. The Classic approach of Barron and Kenny (1986) and contemporary approach of Kenny (2012) were applied for data analysis. The two approaches were compared and analyzed. Descriptive, correlation and regression analysis were applied. These tests have used for analysis of different variables.

\section{Results}

\subsection{Correlation}

Table 1. Correlation among variables

\begin{tabular}{clllll}
\hline \multicolumn{2}{c}{ Variable } & 1 & 2 & 3 & 4 \\
\hline 1 & Role ambiguity & - & & \\
2 & Role Conflict & $.241^{* *}$ & - & & \\
3 & Job Stress & $.243^{* *}$ & $.411^{* *}$ & - & - \\
4 & Job Satisfaction & $-.391^{* *}$ & $-.224^{* *}$ & $-.188^{* *}$ & \\
\hline
\end{tabular}

There is positive correlation between role ambiguity and role conflict $(0.241)$. The correlation value of role ambiguity and job stress is 0.243 and the relationship is positive and significant. There is negative correlation between role ambiguity and job satisfaction (-.391). There is positive and significant correlation between role conflict and job Stress $(0.411)$. The correlation between role conflict and job satisfaction is negative (-.224). In this study the correlation value between job stress and job satisfaction is negative (-.188).

\subsection{Mediation Analysis}

\subsubsection{Classic Approach of Baron and Kenny (1986) for Mediation}

The Barron and Kenny's (1986) model of three steps regression is going to be run. Barron and Kenny's (1986) four steps can be narrated by following three necessitations.

1) Between the independent, dependent and mediator variables, relationship is established by using the regression analysis.

2) The paths in the variables (Independent, Dependent and Mediator) should be statistically significant by using 
the proper procedure.

3) In the situation where the mediation between variables is not zero, there would be partial mediation. If the mediation between variables is zero, then there would be complete mediation and this complete mediation is called perfect mediation.

So for this purpose the following econometric estimations or equations are specified as.

\section{Steps No 1:}

$$
\begin{aligned}
& \text { Job Satisfaction }=c_{0}+c_{1} \text { Role Ambiguity }+c_{2} \text { Role Conflict }+e_{1} \\
& =2.293+0.363 \text { Role Ambiguity }-0.131 \text { Role Conflict }+e \\
& (0.055) \quad(0.052) \\
& (6.628) \quad(-2.544) \\
& (0.000) \quad(0.000)
\end{aligned}
$$

$F=31.83\{0.000\} R^{2}=0.153 R_{\text {Adjusted }}^{2}=0.150$

(The figures above are the $1^{\text {st }}, 2^{\text {nd }}$ and $3^{\text {rd }}$ are parentheses, which represented the Standard Errors, t-ratios and the p-values. These values may be seen in the tables with the heading of additional results).

\section{Step 2:}

$$
\begin{aligned}
\text { Job Stress } & =a_{0}+a_{1} \text { Role Ambiguity }+a_{2} \text { Role Conflict }+e_{2} \\
& =2.527+1.45 \text { Role Ambiguity }-0.387 \text { Role Conflict }+e 2 \\
(0.057) & (0.051)
\end{aligned}
$$

$F=39.43\{0.000\} R^{2}{ }_{\text {Adjusted }}=0.202$

\section{Step 3 (and 4):}

$$
\begin{aligned}
& \text { Job Satisfaction }=c_{0}+c_{1} \text { Role Ambiguity }+c_{2} \text { Role Conflict }+b \text { Job Stress }+e_{3} \\
& =2.185+0.327 \text { Role Ambiguity - 0.168 Role Conflict }+0.224 \text { Job Stress }+e_{3} \\
& (0.055) \quad(0.057) \quad(0.058) \\
& (6.100) \quad(-1.814) \quad(-1.888) \\
& (0.000) \quad(0.017) \quad(0.000)
\end{aligned}
$$

$$
F=29.204\{0.000\} R_{\text {Adjusted }}^{2}=0.157
$$

The Barron and Kenny's (1986) mediation model has been applied. In four steps of model, the contribution of job stress variable is substantial and statistically significant $(b=0.224, p=0.000)$ in the $3^{\text {rd }}$ step of the above equations. Due to the inclusion of job stress (JS) variable in step 4, the independent variables [Role ambiguity (RA) and Role conflict (RC)] decreased from $c_{1}=0.363$ in (Step 1) to $c_{1}^{\prime}=0.327$, however, according to the condition for complete mediation the value of c' did not turn to zero. This fulfills the condition for 'job stress' (JS) being a mediator, but since the involvement or contributions of the variables, role ambiguity and role conflict variables are still significant statistically. The job stress variable is therefore partially mediating between the variables. The study also supports the study of Preacher \& Hayes, 2004. As far as the hypotheses for mediations are concerned, the hypothesis about the mediation in this study is accepted.

\subsubsection{Contemporary Approach of Kenny (2012) for Mediation}

1) The contemporary analysis focuses on the indirect effect of independent variable on dependent variable.

2) In above analysis the steps of mediation were stated in terms of zero and nonzero coefficients and not in term of statistical significance.

3) According to the contemporary analysts, steps 2 and 3 are essential for mediation and not steps 1 and 4 .

Kenny (2012) mediation analysis focuses on the total effect of independent variable (X) on dependent variable (Y) through direct effect (c) and the indirect (meditational) effect ( $\left.c^{\prime}\right)$ through the product of (a and b), so:

$$
\begin{gathered}
\text { Total effect }=\text { Direct effect }+ \text { Indirect effect } \\
\qquad c=c^{\prime}+a b
\end{gathered}
$$




$$
\begin{aligned}
\text { Direct effect }(\%) & =\left(c^{\prime} / c\right) \times 100 \\
\text { Indirect effect }(\%) & =(a b / c) \times 100
\end{aligned}
$$

The values of $\mathrm{c}^{\prime}$, a, and b are known in above A, B and C equations. But according to the Kenny's (2012) approach of mediation; the $1^{\text {st }}$ and $4^{\text {th }}$ steps are not essential for mediation, so equations $\mathrm{B}$ and $\mathrm{C}$ are used in Kenny's (2012) mediation. In equations A, B and C; the role conflict variable carries a negative sign. So role conflict is "inconsistent candidate" for mediation analysis. The "inconsistent mediation" cases have been discussed in Kenny's (2012) webpage.

Table 2. Total effect, direct effect and indirect effect

\begin{tabular}{cc}
\hline Coefficients & Role Ambiguity \\
\hline $\mathrm{a}$ & 1.450 \\
$\mathrm{~b}$ & 0.224 \\
$\mathrm{c}$ & 0.327 \\
$\mathrm{ab}$ & 0.3248 \\
$\mathrm{c}=(\mathrm{c} / \mathrm{ab})$ & 0.6518 \\
Direct effect $(\mathrm{c} / / \mathrm{c})$ & 0.5017 \\
Indirect effect $(\mathrm{ab} / \mathrm{c})$ & 50.17 \\
$\%$ & 0.4983 \\
\hline
\end{tabular}

Table 2 uses the formulas for estimating the direct effect of role ambiguity, which exerts 50.17 percent. While the indirect effect (meditational effect) of "job stress" relative to the variable estimates at 49.83 percent. Whether "job stress" mediates significantly to the respective total effect? According to the Kenny's (2012) approach, statistical significance of 'ab' should be checked by decomposing 'ab' by one of the following measures.

\section{Testing a and b separately}

II. Using Sobel test

\section{Bootstrapping}

\section{Testing "a" and "b" Separately}

In step 2 the Hypothesis $\mathrm{H}_{\mathrm{o}}: \mathrm{a}=0$ and the $\mathrm{p}$-value of a1 is 0.011 , while in step 3 the hypothesis $\mathrm{H}_{\mathrm{o}}: \mathrm{b}=0$ and the p-value is 0.000 . So on the basis of contemporary approach, the Mediational/indirect effect (ab) of the variable role ambiguity appears to be statistically significant, which seems to have the Mediational effect.

\section{Sobel Test}

This test was developed by Micheal E Sobel in 1982 and popularized statistically based methods for mediation by Mackinnon \& Dwyer, (1993). The following equation is used for Sobel test,

$$
\begin{gathered}
\mathrm{Z}_{\mathrm{ab}}=\mathrm{ab} / \mathrm{s}_{\mathrm{ab}} \\
\& \\
\mathrm{~s}_{\mathrm{ab}}=\sqrt{ }\left(\mathrm{a}^{2} \mathrm{~s}_{\mathrm{b}}^{2}+\mathrm{b}^{2} \mathrm{~s}_{\mathrm{a}}^{2}\right)
\end{gathered}
$$

Where $s_{a}$ and $s_{b}$ are the standard errors of $a$ and $b$, respectively.

Table 3. Sobel test computation

\begin{tabular}{cc}
\hline Sobel test computations & Role ambiguity \\
\hline $\mathrm{a}^{2}$ & 2.1025 \\
$\mathrm{~b}^{2}$ & 0.050176 \\
$\mathrm{~s}_{\mathrm{a}}$ & 0.057 \\
$\mathrm{~s}_{\mathrm{b}}$ & 0.058 \\
$\mathrm{~s}_{\mathrm{a}}^{2}$ & 0.003249 \\
$\mathrm{~s}_{\mathrm{b}}^{2}$ & 0.003364 \\
$\mathrm{a}^{2} \mathrm{~s}_{\mathrm{b}}$ & 0.00707281 \\
$\mathrm{~b}^{2} \mathrm{~s}_{\mathrm{a}}$ & 0.000163021 \\
$\mathrm{~s}_{\mathrm{ab}}$ & 0.08506369 \\
$\mathrm{Z}_{\mathrm{ab}}$ & 3.81831543 \\
\hline
\end{tabular}


Table 3 provides the detailed computations of Sobel test by using the above equations. The value of $Z_{a b}$ is (3.81831543) falls out of the interval of $1.96 \pm$ and this suggests that the indirect effect/meditational effect in respect of variable, role ambiguity is statistically significant.

\section{Findings}

This study explains the relationship among role stressors (Independent), job satisfaction (Dependent) and job stress (Mediator) by applying classic and contemporary approaches of mediation. In the classic approach of mediation, four steps mediation is required by applying the three regression equations as explained earlier. In the study, it was found that role stressors and job satisfaction have negative relationship and support the studies of Bhagat et al. (1985), Netemeyer et al. (1990). The job stress and job satisfaction have negative relationship. This study also supports the studies of Melamed et al. (1991), Xie and John (1995) and Jamal and Baba (1992) which also state that job stress was negatively correlated with job satisfaction and positively correlated with role ambiguity and overload. In the above study, the relationship between job stress and role stressors was positive. The Global Job Satisfaction correlated negatively with role ambiguity and role conflict (Birnbaum \& Somers, 1993) and (Pond \& Geyer, 1991). According to the regression analysis, the job stress mediates the influence among role ambiguity, role conflict and job satisfaction. The regression was reduced from 0.391 to 0.367 and the $\mathrm{R}$ Square was reduced from 0.162 to 0.127 . The mediational role of job stress between role conflict and job satisfaction was also mediated. The Beta was reduced from 0.243 to 0.176 and the R Square was reduced from 0.61 to 0.026 .

While by applying the contemporary approach of Kenny (2012), the mediation results of role conflict and role ambiguity were different and narrowed down to the role ambiguity only. The Kenny's (2012) approach rejects the mediation of job stress between role conflict and job satisfaction, because the mediation of job stress between role conflict and job satisfaction contains the "Inconsistent Mediation". The Kenny's (2012) contemporary approach rejects this kind of mediation. As explained earlier about contemporary approach the total, direct and indirect effects have been found out. So the significance was checked by testing "a" and "b" and was valued as $(p$-value $=0.000)$. This value shows significance between role ambiguity and job satisfaction by applying job stress as mediator.

\section{Research Implication}

This nature of study raises the monitor manner of the administrators of the work environment, identify and observe the factors that may increase or decrease job satisfaction. The banking employees identified that controlled role stressors would increase the level of job satisfaction. The employees would be more committed to banking sector when employees are provided a proportionate amount of stress and equality to handle. Subsequently the useful findings implication is reducing the job stress as low as possible even when other role stressors are high. Our findings suggest that much of the impact of role stressors on job satisfaction if the administration lineup can discover techniques to reduce conflict, so in this case the management will be able to keep their employees satisfied even though role stressors are high.

\section{Limitations, Suggestions for Future Research}

The geographical limitation of this study is an elementary limitation. Data was gathered from banking sectors and was limited to Rawalpindi and Islamabad cities only. In this association, the outcome of this study may not be to other organization universal in other businesses, the validity of our findings cannot be generalized to other incumbents in other businesses sectors.

There are two important suggestions for the organization. The $1^{\text {st }}$ one is, the operational procedure should be improved in retail banking. The $2^{\text {nd }}$ one is, the employees should be trained when the employees are assigned a new work or task and guidance should be provided related to the job or duty which will clearly define the role expectations and the responsibilities for the purpose to trim down the role conflict and role ambiguity.

Several lines of research suggest themselves. First, a comparison between managerial and non-managerial clerical staff in terms of perceptions of role ambiguity and role conflict, as sources of stress would be of interest. Second, a comparison between managers of public and private sector commercial banks in terms of perceptions of role stress would also be worthwhile. Third, the study of the impact of demographic variables on the perceptions of role overload and role conflict as sources of stress is of interest.

\section{Conclusion of the Study}

The study was conducted on the banking sector of Islamabad and Rawalpindi, Pakistan. As the Baron and Kenny (1986) model has been used for the data analysis for mediation. This Baron and Kenny's (1986) mediation model is also called the Classic Approach of mediation. The relationship of variables were significant and according to 
the correlation and regression analysis and by using the Barron and Kenny's (1986) equations it has been concluded that the mediator (job stress) mediates among the variables, role ambiguity, role conflict and job satisfaction. The study reveals that role ambiguity has a strong influence and negative relation with job satisfaction. The relationship between job stress and role ambiguity was measured as positive. The relation between job stress and job satisfaction was measured as negative. By applying the contemporary approach of mediation the step 2 and step 4 were taken into consideration and step 1 and step 2 were excluded as unnecessary. The classic approach tells about the significant paths between variables and the indirect relationship " $\mathrm{c}$ ' $=0$ " significant for complete mediation while " $c^{\prime} \neq 0$ " for partial mediation. In the contemporary approach the focus is on indirect effect of independent variable on dependent variable and mediation is stated in term of zero and nonzero and statistical significance. The contemporary approach (2012) of mediation has the quantifying mediation effect on classic approach (1986). The classic approach indicates the partial mediation while the contemporary approach not only indicates the mediation but also the tests the non-zero effect but also zero effect and other variable differentiation.

Results from this study designates that owners are required to take steps to decrease role stress and increase job satisfaction in different dimensions of their jobs. However, the changes which will improve one dimension of the job satisfaction may not be related to increase job satisfaction in a different dimension.

\section{References}

Adkins, C. L. (1995). Previous work experience and organizational socialization: A longitudinal examination. Academy of Management Journal, 38(3), 839-867. http://dx.doi.org/10.2307/256748

Ahmad, A., \& Ngah, N. (2007). Role conflict, work-family conflict and job satisfaction among single mother employees. University Putra Malaysia, Malaysia.

Ahmadi, K., \& Alireza, K. (2007). Stress and Job Satisfaction among Air Force Military Pilots. Journal of Social Sciences, 3(3), 159-163. http://dx.doi.org/10.3844/jssp.2007.159.163

Ahsan, N., \& Abdullah, Z., Gun Fie, D. Y., \& Alam, S. S. (2009). A Study of Job Stress on Job Satisfaction among University Staff in Malaysia: Empirical Study. European Journal of Social Sciences, 8(1), 121-131.

Aziz, M. (2004). Role stress among Indian information technology sector. Women in Management Review, 19(7), 356-363. http://dx.doi.org/10.1108/09649420410563412

Babin, B. J., \& Boles, J. S. (1996). The Effects of Perceived Co-Worker Involvement and Supervisor Support on Service Provider Role Stress, Performance and Job Satisfaction. Journal of Retailing, 72, 57-76. http://dx.doi.org/10.1016/S0022-4359(96)90005-6

Baroudi, J. J. (1985). The Impact of Role Variables on IS Personnel Work Attitudes and Intentions. MIS Quarterly, 9(4), 341-356. http://dx.doi.org/10.2307/249234

Barron, R., \& Kenny, D. (1986). The moderator variable distinction in Social Psychological research conceptual, strategic, and statistical consideration. Journal of Personality and Social Psychology, 51(6), 1173-1182. http://dx.doi.org/10.1037/0022-3514.51.6.1173

Bedeian, A. G., \& Armenakis, A. A. (1981). A Path-Analytic study of the Consequences of Role Conflict and Ambiguity. Academy of Management Journal, 24, 417-424. http://dx.doi.org/10.2307/255852

Bedeian, A. G., Beverly, G. B., \& Richard, G. M. (1988). Outcomes of Work-Family Conflict among Married Male and Female Professionals. Journal of Management, 14(3), 475-491. http://dx.doi.org/10.2307/249234

Bhagat, R. S., McQuaid, S. J., Lindholm, H., \& Segovis, J. (1985). Total life stress: A multimethod validation of the construct and its effects on organizationally valued outcomes and withdrawal behaviors. Journal of Applied Psychology, 70, 202-241. http://doi.apa.org/journals/apl/70/1/202

Birnbaum, D., \& Somers, M. J. (1993). Fitting job performance into a turnover model: An examination of the form of the job performance turnover relationship and path model. Journal of Management, 19(1), 1-11. http://dx.doi.org/10.1177/014920639301900101

Bradley, J. R., \& Cartwright, S. (2002). Social support, job stress, health, and job satisfaction among nurses in the United Kingdom. International Journal of Stress Management, 9(3), 163-182. http://dx.doi.org/10.1023/A:1015567731248

Chen, M. F., \& Lien, G. Y. (2008). The Mediating Role of Job Stress in Predicting Retail Banking Employee's Turnover Intentions in Taiwan. IEEE, 1, 393-398. http://dx.doi.org/10.1109/SOLI.2008.4686427

Coleman, J. C. (1976). Abnormal Psychology and modern life. Taraporewalla: Bombay. 
Cooper C. L., \& Dewe, P. J. (2004). Stress: A Brief History. Oxford: Blackwell. http://dx.doi.org/10.1002/9780470774755

Cooper, C., Rout, U., \& Faragher, B. (1989). Mental Health, Job Satisfaction, and Job Stress among General Practitioners. Medical Journal, 298, 366-370. http://dx.doi.org/10.1136/bmj.298.6670.366

Cox, T., Griffiths, A., Barlowe, C., Randall, K., Thomson, L., \& Rial-Gonzalez, E. (2000). Organizations Interventions for work Stress: A risk management approach. Sudbury: HSE books.

Cummins, R. C. (1990). Job stress and the buffering effort of supervisory support. Group and Organizational Studies, 15(1), 92-104. http://dx.doi.org/10.1177/105960119001500107

Fisher, C. D., \& Gittleson, R. (1983). A meta-analysis of correlates of role conflict and ambiguity. Journal of Applied Psychology, 68, 320-333. http://dx.doi.org/10.1037/0021-9010.68.2.320

Fletcher, J. B., \& Payne, R. (1980). Stress and Work: A Review and a Theoretical Framework, Part 1. Personnel Review, 9, 1-20. http://dx.doi.org/10.1108/eb0554000

Goldstein, D., \& Rockart, J. (1984). An Examination of Work-Related Correlates of Job Satisfaction in Programmer/Analysts. MIS Quarterly, 8(2), 103-115. http://dx.doi.org/10.2307/249347

Goolsby, J. R. (1992). A Theory of Role Stress in Boundary Spanning Positions of Marketing Organizations. Journal of the Academy of Marketing Science, 20, 155-164. http://dx.doi.org/10.1007/BF02723455

Higgins, C. A., Duxbury, L. E., \& Irving, R. K. (1992). Work-family conflict in the dual career family. Organizational Behavior and Human Decision Processes, 51, 51-57. http://dx.doi.org/10.1016/0749-5978(92)90004-Q

Hobfoll, S. E. (1989). Conservation of resources: A new attempt at conceptualizing stress. American Psychologist, 44, 513-524. http://dx.doi.org/10.1037/0003-066X.44.3.513

Jackson, S. (1983). Participation in decision making as a strategy for reducing job-related strain. Journal of Applied Psychology, 68(1), 3-19. http://dx.doi.org/10.1037/0021-9010.68.1.3

Jackson, S., \& Schuller, R. (1985). A meta analysis and conceptual critique of research on role ambiguity and role conflict in working stress. Organizations Behavior and Human Decision Process, 36, 16-78. http://dx.doi.org/10.1016/0749-5978(85)90020-2

Jamal, M., \& Baba, V. V. (1992). Shift work and department type related to job stress work attitudes and behavioral intentions: A study of Nurses. Journal of Organizational Behavior, 13, 449-464. http://dx.doi.org/10.1002/job.4030130503

James, S., Boles, W. J. A., \& Johnson, J. (2003). Interrelationships of role conflict, role ambiguity, and work-family conflict with different facets of job satisfaction and the moderating effects of gender. Journal of Personal Selling \& Sales Management, 23(2), 99-113.

Johnston, M. W., Parasuraman, A., \& Futrell, C. M. (1990). Extending a model of salesperson role perceptions and work-related attitudes: Impact of job tenure. Journal of Business Research, 18, 269-290. http://dx.doi.org/10.1016/0148-2963(89)90022-2

Kahn, R. L., Wolfe, D. M., Quinn, R. P., Snoek, J. D., \& Rosenthal, R. A. (1964). Organizational Stress: Studies in Role Conflict and Ambiguity. New York, America: John Wiley \& Sons.

Kenny, D. A. (2012). Mediation. Retrieved from http://www.DavidaKenny.net

Konstantinos, N., \& Christina, O. (2008). Factors Influencing Stress and Job Satisfaction of Nurses Working In Psychiatric Units: A Research Review. Health Science Journal, 2(4), 183-195. http://hdl.handle.net/11400/1207

Landsbergis, P. A. (1988). Occupational stress among health care workers: A test of the job demands-control model. Journal of Organizational Behavior, 9, 217-239. http://dx.doi.org/10.1002/job.4030090303

Larson, L. L. (2004). Internal auditors and job stress. Managerial Auditing Journal, 19(9), 1119-1130. http://dx.doi.org/10.1108/02686900410562768

Lourel, M., Ford, M. T., Gamassou, C. E., Gueguen, E., \& Hartmann, A. (2009). Negative and positive spillover between work and home: Relationship to perceived stress and job satisfaction. Journal of Managerial Psychology, 24(5), 438-449. http://dx.doi.org/10.1108/02683940910959762

Lu, L., Tseng, H., \& Cooper, C. L. (1999). Managerial stress, job satisfaction, and health in Taiwan, Stress 
Medicine, 15, 53-64. http://dx.doi.org/10.1108/02686900410562768

MacKinnon, D. P., \& Dwyer, J. H. (1993). Estimating mediated effects in prevention studies. Evaluation Review, 17, 144-158. http://dx.doi.org/10.1177/0193841X9301700202

Malik, O. F., Waheed, A., \& Malik, K. Ur. R. (2010). The Mediating Effects of Job Satisfaction on Role Stressors and Affective Commitment. International Journal of Business and Management, 5(11), 223-235. http://dx.doi.org/10.5539/ijbm.v5n11p223

Melamed, S., Kushnin, T., \& Meir, E. I. (1991). Attenuating the impact of job demands: Additive and interactive effects of perceived control and social support. Journal of Vocational Behavior, 39, 40-53. http://dx.doi.org/10.1016/0001-8791(91)90003-5

Moncrief, C. W., Babakus, E., Cravens, W. D., \& Johnston, M. (1997). Examining the antecedents and consequences of salesperson job stress. European Journal of Marketing, 31(11/12), 786-798. http://dx.doi.org/10.1108/03090569710190532

Netemeyer, R. G., Johnston, M. W., \& Burton, S. (1990). Analysis of role conflict and ambiguity in structured equations framework. Journal of Applied Psychology, 75, 148-157. http://dx.doi.org/10.1037/0021-9010.75.2.148

Nobile, J. D., \& McCormick, J. (2005). Job Satisfaction and Occupational Stress in Catholic Primary Schools. Association for Research in Education, Sydney.

Pareek, U. (1993). Making organizational roles effective. New Delhi: Tata McGraw Hill.

Pond, S. B., \& Geyer, P. D. (1991). Differences in the relation between job satisfaction and perceived work alternatives among older and younger blue-collar workers. Journal of Vocational Behavior, 39, 251-262. http://dx.doi.org/10.1016/0001-8791(91)90012-B

Preacher, K. J., \& Hayes A. F. (2004). SPSS and SAS procedures for estimating indirect effects in simple mediation models. Behavior Research Methods, Instruments, \& Computers, 36(4), 717-731. http://dx.doi.org/10.3758/BF03206553

Quinn, R. P., Thomas, W. M., \& Stanley, E. S. (1974). Quality of Employment Survey, 1972-1973. ICPSR03510-v1. Ann Arbor, MI: Inter-university Consortium for Political and Social Research. http://doi.org/10.3886/ICPSR03510.v1

Ram, N., Khoso, I., Shah, A. A., Chandio, F. R., \& Sheikh, F. M. (2011). Role conflict and role ambiguity as factors in work stress among managers: A case study of manufacturing sector in Pakistan. Canadian Center of Science and Education, 7(2), 113-118. http://dx.doi.org/10.5539/ass.v7n2p113

Rice, R. W., Gentile, D. A., \& McFarlin, D. B. (1991). Facet importance and job satisfaction. Journal of Applied Psychology, 76(1), 31-39. http://dx.doi.org/10.1037/0021-9010.76.1.31

Rizzo, J. R., House, R. J., \& Lirtzman, S. I. (1970). Role conflict and ambiguity in complex organizations, Administrative Science Quarterly, 15(2), 150-163. http://dx.doi.org/10.2307/2391486

Robbins, S. P. (1997). Organizational Behavior. Prentice Hall.

Robbins, S. P. (2007). Organizational Behavior (10th ed.). Prentice-Hall, Inc., New Jersey.

Robinson, S. E., Roth, S. L., \& Brown, L. L. (1993). Morale and job satisfaction among nurses: What can hospitals do? Journal of Applied Social Psychology, 23(3), 244-251. http://dx.doi.org/10.1111/j.1559-1816.1993.tb01085.x

Safaria, T., Othman, A., \& Wahab, M. N. A. (2011). Role Ambiguity, Role Conflict, the Role of Job Insecurity as Mediator toward Job Stress among Malay Academic Staff: A SEM Analysis. Current Research Journal of Social Sciences, 3(3), 229-235.

Sager, J. K. (1994). A structural model depicting salespeople's job stress. Journal of the Academy of Marketing Science, 22(1), 74-84. http://dx.doi.org/10.1177/0092070394221007

Schaefer, J. A., \& Moos, R. H. (1993). Relationship, task and system stressors in the healthcare Workplace. Journal of Community and Applied Social Psychology, 3(4), 285-298. http://dx.doi.org/10.1002/casp.2450030406

Shenkar, O., \& Zeira, Y. (1991). Role Conflict and Role Ambiguity of Chief Executive Officers in International Joint Ventures. Journal of International Business Studies, 23(1), 55-75. 
Singh, J., Goolsby, J. R., \& Rhoads, G. K. (1994). Behavioral and psychological consequences of boundary spanning burnout for customer service representatives. Journal of Marketing Research, 31(4), 558-569. http://dx.doi.org/10.2307/3151883

Sobel, M. E. (1982). Asymptotic Confidence Intervals for Indirect Effects in Structural Equation Models. Sociological Methodology, 13, 290-312. http://dx.doi.org/10.2307/270723

Sobel, M. E. (1986). Some new results on indirect effects and their standard errors in covariance structure. Sociological Methodology, 16, 159-186. http://dx.doi.org/10.2307/270922

Stamps, P. L., \& Piedmonte, E. B. (1986). Nurses and work satisfaction: An index for measurement. Ann Arbor, MI: Health Administration Press Perspectives. http://dx.doi.org/10.1057/palgrave.jibs.8490259

Sulksky, L., \& Smith, C. (2005). Work Stress. California: Thomson Wadsworth.

Sullivan, S. E., \& Bhagat, R. S. (1992). Organizational stress, job satisfaction and job performance: Where do we go from here? Journal of Management, 18(2), 353-374. http://dx.doi.org/10.1177/014920639201800207

Usman, A., Ahmed, Z., \& Ahmed, I. (2011). Work Stress Experienced by the Teaching Staff of University of the Punjab, Pakistan: Antecedents and Consequences. International Journal of Business and Social Science, 2(8), 202-210.

Vinokur-Kaplan, J. X. (1991). Job Satisfaction among Social Workers in Public and Voluntary Child Welfare Agencies. Child Welfare, 70(1), 81-91.

Wu, L., \& Norman, I. J. (2006). An investigation of job satisfaction, organizational commitment and role conflict and ambiguity in a sample of Chinese undergraduate nursing students. Nurse Education Today, 26(4), 304-314. http://dx.doi.org/10.1016/j.nedt.2005.10.011

Xie, J. L., \& John, G. (1995). Job scope and stress: Can job scope be too high? Academy of Management Journal, 38(5), 1288-1309. http://dx.doi.org/10.2307/256858

Yousef, D. A. (2000). The interactive effects of role conflict and role ambiguity on job satisfaction and attitudes toward organizational change: A moderated multiple regression approach. International Journal of Stress Management, 7(4), 289-303. http://dx.doi.org/10.1023/A:1009593913606

Yousef, D. A. (2002). Job satisfaction as a mediator of the relationship between role stressors and organizational commitment: A study from an Arabic cultural perspective. Journal of Managerial Psychology, 17(4), 250-266. http://dx.doi.org/10.1108/02683940210428074

\section{Copyrights}

Copyright for this article is retained by the author(s), with first publication rights granted to the journal.

This is an open-access article distributed under the terms and conditions of the Creative Commons Attribution license (http://creativecommons.org/licenses/by/3.0/). 